\title{
Pengembangan Modul Interaktif Pada Mata Pelajaran IPA Terpadu Kelas VIII
}

\author{
Joko Kuswanto ${ }^{1}$ \\ ${ }^{1}$ Program Studi Teknologi Pendidikan Universitas Baturaja \\ Jl. Ki Ratu Penghulu No. 02301 Karang Sari Telepon (0735) 326122 Fax. 321822 \\ Baturaja - 32113 OKU Sumatera Selatan e-mail: ko.8515@gmail.com
}

\begin{abstract}
One form of teaching materials interactive is module interactive. Interactive module is a unified learning, setting designed to help students individually in achieving the purposes of study. This study aims to develop interactive module on the subjects of integrated IPA class VIII. The research method used is research development with stages of designing, production, evaluation, and analyzing data by percentage. The results of this study indicate that media is learning to interactive module developed on the subjects of integrated IPA class VIII is feasible for use in learning by teachers and students. Based on several stages of trial, the learning media is categorized valid with the level of feasibility of $82 \%$ with good criteria. This research is expected to be a medium of learning on the subjects of integrated IPA class VIII and can be useful for teachers, students, and advanced researchers.
\end{abstract}

Keywords: Interactive Module, Learning Media, Development, IPA

Intisari-Salah satu bentuk bahan ajar interaktif adalah modul interaktif. Modul interaktif merupakan jenis kesatuan kegiatan belajar yang terencana, dirancang untuk membantu para siswa secara individual dalam mencapai tujuan belajarnya. Penelitian ini bertujuan untuk mengembangkan modul interaktif pada mata pelajaran IPA Terpadu kelas VIII. Metode penelitian yang digunakan adalah penelitian pengembangan dengan tahapan perancangan, produksi, evaluasi, dan menganalisis data dengan persentase. Hasil penelitian ini menunjukkan bahwa media pembelajaran berupa modul interaktif yang dikembangkan pada mata pelajaran IPA Terpadu Kelas VIII sudah layak untuk digunakan dalam pembelajaran oleh guru dan siswa. Berdasarkan beberapa tahapan uji coba, modul interaktif dikategorikan valid dengan tingkat kelayakan sebesar $82 \%$ dengan kriteria baik. Penelitian ini diharapkan dapat menjadi media pembelajaran pada mata pelajaran IPA Terpadu Kelas
VIII dan dapat bermanfaat bagi guru, siswa, dan peneliti lanjutan.

Kata Kunci: Modul Interaktif, Media Pembelajaran, Pengembangan, IPA

\section{PENDAHULUAN}

Bahan ajar merupakan sebuah susunan atas bahanbahan yang berhasil dikumpulkan dan berasal dari berbagai sumber belajar yang dibuat secara sistematis [1]. Sebagai seorang pendidik dituntut untuk dapat secara kreatif mendesain suatu bahan ajar yang memungkinkan peserta didik dapat secara langsung memanfaatkan sumber belajar yang tersedia. Guru dituntut untuk lebih kreatif dan inovatif dalam memilih sumber belajar, media ajar yang baik agar tercipta kegiatan pembelajaran yang lebih aktif, kreatif, inovatif, dan menyenangkan sehingga tercipta multi interaksi di kelas [2]. Bahan ajar memiliki berbagai jenis dan bentuk, adapun jenis bahan ajar menurut bentuknya yaitu: bahan cetak (printed), bahan ajar dengar (program audio), bahan ajar pandang dengar (audiovisual), dan bahan ajar interaktif (interaktif teaching materials).

Bahan ajar interaktif yaitu multimedia yang merupakan kombinasi dari dua arah atau lebih media (audio, text, grafhics, images, animation, and video) yang oleh penggunanya dimanipulasikan untuk mengendalikan perintah dan atau perilaku alami dari suatu presentasi [3] Salah satu bentuk bahan ajar interaktif adalah modul interaktif. Modul interaktif merupakan jenis kesatuan kegiatan belajar yang terencana, dirancang untuk membantu para siswa secara individual dalam mencapai tujuan belajarnya. Para siswa dapat mengikuti program pengajaran sesuai dengan kecepatan dan kemampuan sendiri, lebih 
banyak belajar mandiri, dapat mengetahui hasil belajarnya sendiri.

Keberadaan modul interaktif memberi pengaruh dalam proses belajar mengajar, sehingga penyusunan modul interaktif harus disusun sesuai dengan kebutuhan pada mata pelajaran tertentu misalnya mata pelajaran IPA Terpadu. Modul interaktif dapat menjadi bahan ajar yang menarik dan memotivasi siswa untuk belajar. Kalimat harus disusun dengan sederhana, singkat, jelas, dan efektif, sehingga mempermudah siswa dalam memahaminya. Didukung dengan adanya gambar-gambar yang dapat memperjelas isi materi sehingga menambah daya tarik dan mengurangi kebosanan siswa untuk mempelajarinya.

Tujuan dari penelitian ini adalah untuk membuat modul interaktif pada mata pelajaran IPA Terpadu kelas VIII. Penelitian ini diharapkan dapat menghasilkan produk berupa bahan ajar yang sesuai dengan kebutuhan siswa kelas VIII serta sesuai dengan kurikulum dan silabus yang berlaku.

\section{Tinjauan Pustaka}

\section{A. Bahan Ajar}

Bahan ajara dalah segala bentuk bahan yang digunakan untuk membantu guru atau instruktur dalam melaksanakan kegiatan belajar mengajar. Bahan yang dimaksud bisa berupa bahan tertulis maupun tidak tertulis [3]. Pemilihan bahan ajar harus mendasarkan diri pada tujuan artinya bahan hanya diambil jika mempunyai relevansi dengan kompetensi yang dibelajarkan. Pemilihan bahan ajar yang tidak sesuai dengan kompetensi yang dimaksud maka berakibat tidak tercapainya tujuan yang diinginkan [1].

\section{B. Manfaat Bahan Ajar}

Manfaat bahan ajar bagi pendidik dan peserta didik adalah sebagai berikut [1]:

1. Pendidik akan memiliki bahan ajar yang dapat membantu dalampelaksanaan kegiatan pembelajaran.

2. Bahan ajar dapat diajukan sebagai karya yang dinilai untuk menambah angka kredit pendidik guna keperluan kenaikan pangkat.

3. Menambah penghasilan bagi pendidik jika hasil karyanya diterbitkan.
4. Kegiatan pembelajaran menjadi lebih menarik.

5. Peserta didik lebih banyak mendapatkan kesempatan untuk belajar secara mandiri dengan bimbingan pendidik.

6. Peserta didik mendapatkan kemudahan dalam mempelajari setiap kompetensi yang harus dikuasainya.

\section{Modul Interaktif}

Modul adalah salah satu bentuk media cetak yang berisi satu unit pembelajaran, dilengkapi dengan berbagai komponen sehingga memungkinkan siswa-siswa yang mempergunakannya dapat mencapai tujuan secara mandiri, dengan sekecil mungkin bantuan dari guru, mereka dapat mengontrol mengevaluasi kemampuan sendiri, yang selanjutnya dapat menentukan mulai darimana kegiatan belajar selanjutnya dilakukan [4].

Interaktif menciptakan hubungan dua arah sehingga dapat menciptakan situasi dialog antara dua atau lebih pengguna. Interaktif dapat meningkatkan kreativitas dan terjadinya umpan balik terhadap apa yang dimasukkan oleh pengguna sehingga pembelajaran bisa dua arah atau lebih apabila dibantu media lain [5].

Jadi modul interaktif adalah modul yang dikembangkan dan dilengkapi dengan beberapa hasil dari program software komputer sehingga modul menjadi interaktif. Bahan ajar cetak yang dikembangkan menjadi program interaktif termasuk membuat modul interaktif. Dikatakan interaktif karena pengguna akan mengalami interaksi dan bersikap aktif misalnya aktif memperhatikan gambar, memperhatikan warna atau gerak, suara, animasi, bahkan video dan film.

Penggunaan modul interaktif sebagai media pembelajaran mempunyai peranan yang penting yaitu modul interaktif memiliki kemampuan dalam menciptakan minat belajar siswa, membantu siswa mempermudah memahami materi pelajaran yang telah disampaikan oleh pendidik, serta modul interaktif memiliki komponen interaktif yang dapat membuat siswa lebih aktif dalam kegiatan pembelajaran [6].

Dalam pemanfaatannya, modul interaktif dengan bantuan komputer dapat membantu peran guru dalam mempresentasikan informasi, menguji melalui evaluasi serta memberikan umpan balik seperti dalam pembelajaran 
berprogram yang melibatkan siswa dalam penyampaian materi [7].

\section{IPA Terpadu}

IPA Terpadu merupakan rumpun, memiliki karakteristik khusus yaitu mempelajari fenomena alam. Baik berupa kenyataan (reality) atau kejadian (event) dan hubungan sebab akibatnya. IPA terpadu adalah suatu kumpulan teori yang sistematis, penerapannya secara umum terbatas pada gejala-gejala alam, lahir dan berkembang melalui metode ilmiah seperti observasi dan eksperimen serta menuntut sikap ilmiah seperti rasa ingin tahu, terbuka, jujur, dan sebagainya. IPA terpadu dibangun atas dasar produk ilmiah, proses ilmiah, dan sikap ilmiah [8]. Dengan demikian IPA terpadu pada hakikatnya adalah ilmu untuk mencari tahu, memahami alam semesta secara sistematik dan mengembangkan pemahaman ilmu pengetahuan tentang gejala alam yang dituangkan berupa fakta, konsep, prinsip, dan hukum yang teruji kebenarannya. Namun, IPA terpadu bukan hanya merupakan kumpulan pengetahuan berupa fakta, konsep, prinsip, melainkan suatu proses penemuan dan pengembangan.

\section{Metodologi Penelitian}

Metodologi yang digunakan dalam penelitian ini adalah penelitian pengembangan. Merupakan penelitian yang berorientasi untuk mengembangkan dan memvalidasi produk-produk yang digunakan dalam pendidikan [9]. Pengembangan modul interaktif ini menggunakan model prosedural yaitu model yang bersifat deskriptif, menunjukkan langkah-langkah yang harus diikuti untuk menghasilkan produk [10]. Langkah-langkah prosedur pengembangan meliputi: tahap perancangan, produksi, dan evaluasi [11].

Subjek dalam penelitian ini yaitu diawali dengan validasi ahli yaitu ahli desain, ahli media, dan ahli materi. Dilanjutkan uji coba produk skala perorangan dengan jumlah responden 3 orang siswa. Selanjutnya uji coba kelompok kecil sebanyak 6 responden. Kemudian dilakukan uji lapangan dengan jumlah responden 34 siswa. Teknik pengumpulan data menggunakan menggunakan angket. Dimana angket digunakan untuk memperoleh informasi serta data untuk mengukur kelayakan produk yang dihasilkan.

\section{IV.PEMBAHASAN}

\section{A. Hasil Penelitian}

Penelitian dan pengembangan ini bertujuan untuk menghasilkan suatu produk media pembelajaran berupa modul interaktif. Langkah dalam menghasilkan produk media pembelajaran ini, peneliti melalui beberapa tahap prosedur kerja, yaitu merancang, memproduksi dan mengevaluasi.

Pada tahap rancangan: didapatkan hasil analisis kebutuhan berupa materi dan silabus mata pelajaran sesuai dengan kurikulum. Pada rancangan menu utama terdapat beberapa tombol, seperti: Petunjuk, SK \& KD, Materi, Evaluasi, Profil. Tahap berikutnya adalah produksi: media yang dikembangkan berupa media audiovisual yaitu penggabungan antara teks, suara, gambar dan animasi. Tahap selanjutnya adalah evaluasi: evaluasi pramaster yang terdiri dari evaluasi ahli, perorangan, dan kelompok kecil kemudian dilanjutkan dengan uji coba lapangan

Hasil akhir dalam penelitian ini yaitu modul interaktif yang digunakan sebagai media pembelajaran. Aplikasi terdiri dari halaman-halaman yang saling terhubung, adapun tampilannya adalah sebagai berikut:

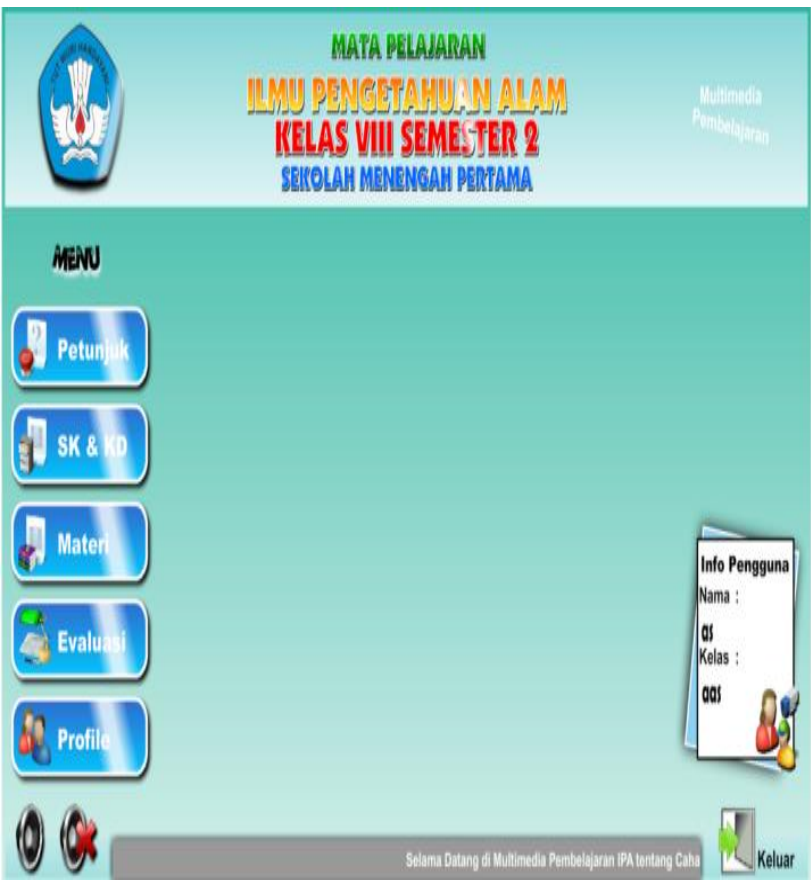

Gambar 1. Tampilan Utama 
Gambar 1 merupakan halaman yang berisi tombol yang berfungsi untuk mempermudah pengguna dalam menjalankan atau mengakses tampilan yang diinginkan. Tombol-tombol yang berada di halaman utama tersebut antara lain Petunjuk, SK \& KD, Materi, Evaluasi, dan Profil.

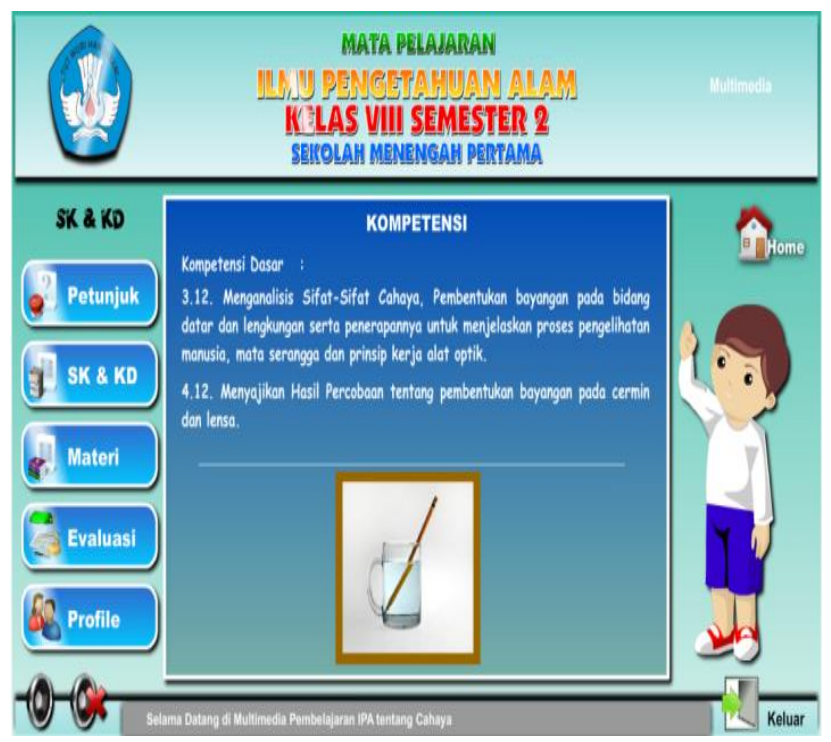

Gambar 2. Tampilan SK \& KD

Gambar 2 halaman kompetensi yang merupakan halaman yang menampilkan Standar Kompetensi dan Kompetensi Dasar yang digunakan dalam modul interaktif.

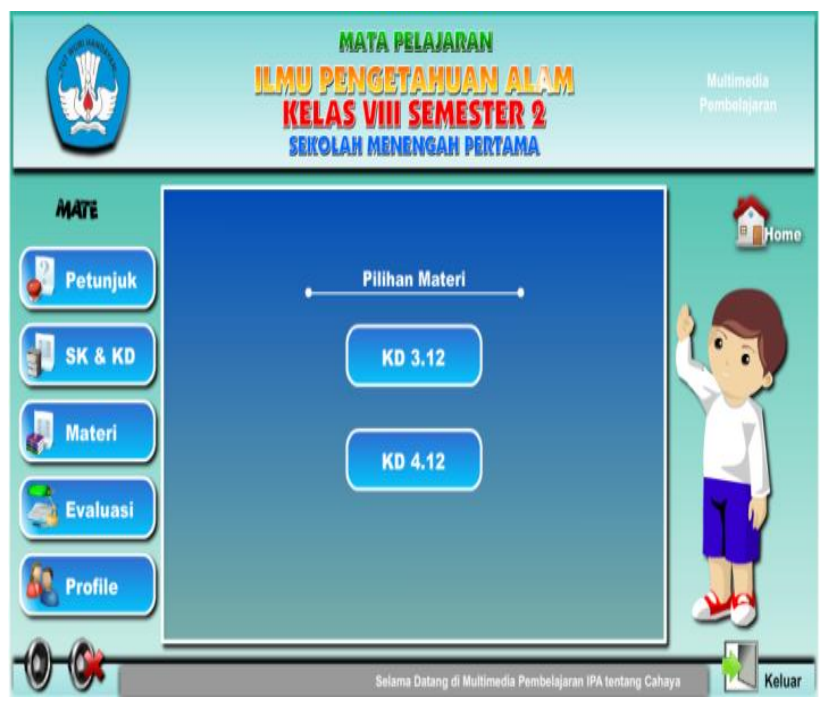

Gambar 3. Tampilan Menu Materi

Gambar 3 tampilan menu materi. Halaman materi merupakan menu yang berisi uraian materi pelajaran IPA Terpadu kelas VIII. Materi tersebut dikembangkan sesuai dengan kurikulum. Jika salah satu menu materi di klik atau dipilih sesuai dengan kompetensi dasar yang ingin di pelajari, maka halaman materi akan ditampilkan. Tampilannya sebagai berikut:

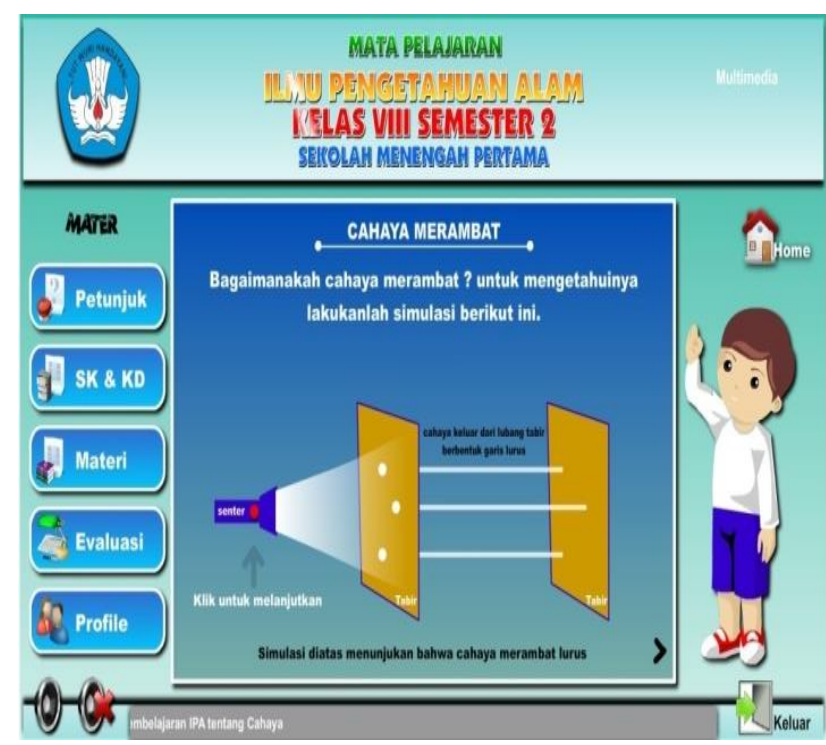

Gambar 4. Tampilan Halaman Materi Sesuai KD

Halaman evaluasi berisi soal-soal yang digunakan untuk mengukur kemampuan siswa melalui produk modul interaktif. Sebelum menuju ke halaman soal pengguna diharuskan megisi biodata terlebih dahulu seperti gambar berikut:

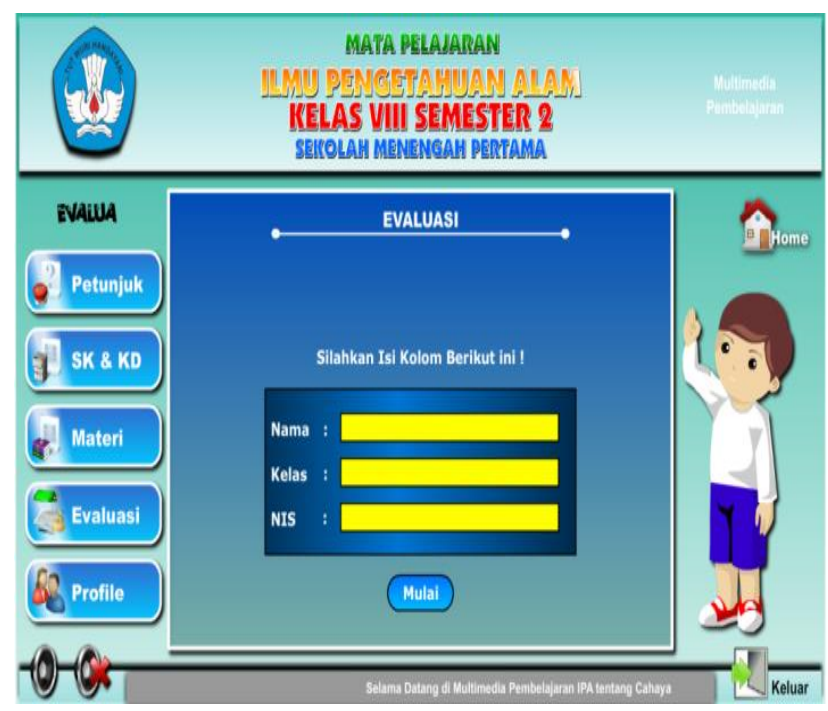

Gambar 6. Tampilan isian data

Setelah isian data terisi, pengguna dapat mengklik tombol mulai untuk menampilkan halaman evaluasi dan memulai mengerjakan soal evaluasi. Tampilannya adalah sebagai berikut: 


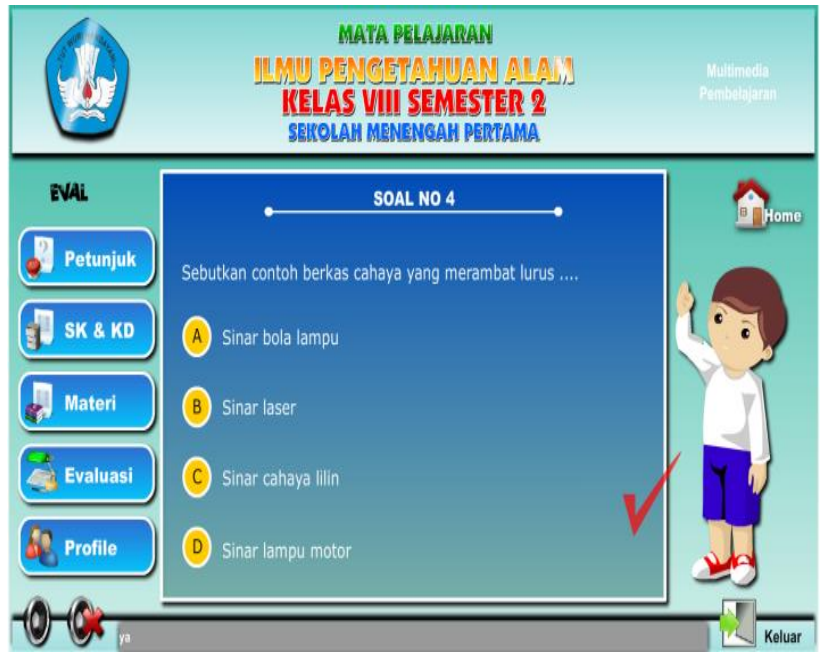

Gambar 7. Tampilan Evaluasi

Pada akhir evaluasi akan ditampilkan perhitungan skor atau nilai berdasarkan jawaban benar dan jawaban salah. Tampilannya adalah sebagai berikut.

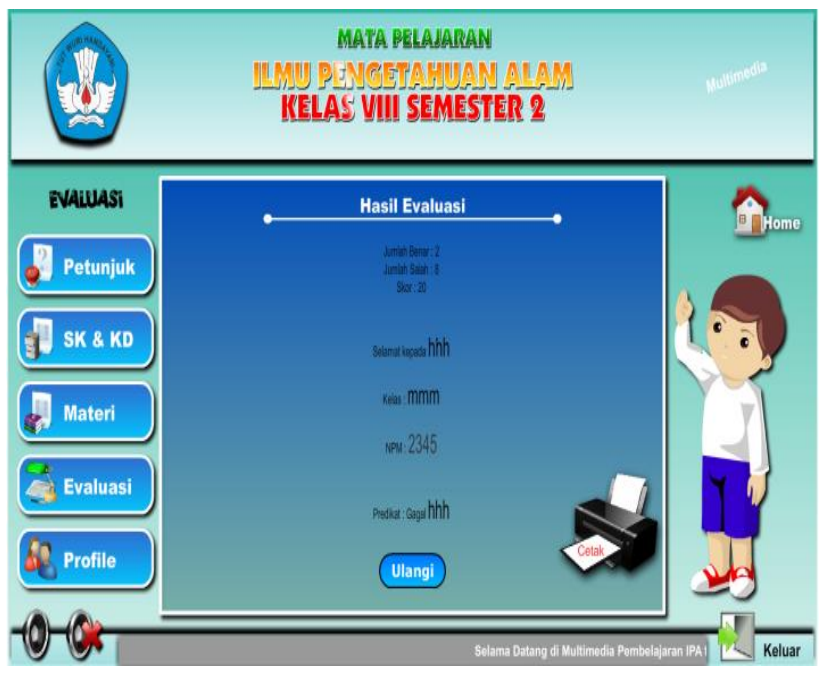

Gambar 8. Tampilan Hasil Evaluasi

\section{B. Pembahasan}

Sesuai dengan tahapan yang sudah dilakukan dalam pembuatan media pembelajaran berupa modul interaktif, dikatakan bahwa modul interaktif ini dikembangan sesuai dengan kurikulum mata pelajaran IPA terpadu kelas VIII.

Modul interaktif ini ini telah melalui tahapan evaluasi pramaster yang diawali dengan para ahli. Untuk validasi atau penilaian yang dilakukan kepada ahli desain, mendapatkan persentase sebesar 82,6 \% dengan kualifikasi baik. Untuk validasi atau penilaian yang dilakukan kepada ahli media, mendapatkan persentase sebesar $80 \%$ dengan kualifikasi baik. Untuk validasi atau penilaian yang dilakukan kepada ahli materi, mendapatkan persentase sebesar 80,3 \% dengan kualifikasi baik. Pada pengujian skala perorangan mendapat predikat baik dengan jumlah persentase sebesar $84 \%$. Untuk hasil pengujian kelompok kecil mendapat predikat baik dengan persentase sebesar $83 \%$. Selanjutnya untuk pengujian lapangan mendapat predikat baik dengan persentase sebesar $82 \%$.

Secara keseluruhan media pembelajaran berupa modul interaktif yang dikembangkan memiliki beberapa kelebihan yaitu penyajian materi pada media yang dikembangkan sesuai dengan kompetensi, media ini mudah dipahami oleh pengguna dan mampu menumbuhkan motivasi belajar bagi pengguna.

Namun selain mempunyai beberapa kelebihan, media pembelajaran ini juga memiliki kekurangan atau kelemahan, yaitu gambar dan video yang digunakan dalam media masih bersumber dari internet.

\section{Daftar Pustaka}

[1] Prastowo, Andi. 2015. Panduan Kreatif Membuat Bahan Ajar Inovatif: Menciptakan Metode Pembelajaran yang Menarik dan Menyenangkan. Yogyakarta: DIVAPress.

[2] Sefriani, Rini \& Indra Wijaya. 2018. Modul Pembelajaran Multimedia Interaktif Berbasis Adobe Director Pada Mata Pelajaran Sistem Operasi Sekolah Menengah Kejuruan. Journal of Information Technology and Computer Science (INTECOMS).. Vol 1 No 1, Maret 2018, 60-71

[3] Majid, Abdul. 2008. Perencanaan Pembelajaran: Mengembangkan Standar Kompetensi Guru. Bandung: PT. Remaja Rosdakarya Offset.

[4] Wena, Made. 2014. Strategi Pembelajaran Inovatif Kontemporer: Suatu Tinjauan Konseptual Operasional. Jakarta: BumiAksara.

[5] Munir. 2012. Multimedia: Konsep \& Aplikasi dalam Pendidikan. Bandung: Alfabeta.

[6] Apriliyah, "Pengembangan Media Pembelajaran Modul Interaktif Pada Materi Jurnal Khusus Kelas X Akuntansi di SMK Negeri Mojoagung”. Skripsi, 
Program Studi Pendidikan Akuntansi, Jurusan Pendidikan Ekonomi, Fakultas Ekonomi, Universitas Negeri Surabaya. 2014.

[7] Arin Dwi Cahyanti, "Pengembangan Media Pembelajaran Modul Interaktif Berbasis Adobe Flash CS 6 Pada Kompetensi Jurnal Penyesuaian Untuk Siswa Kelas XI IPS SMA N 1 Tempel”. Skripsi, Program Studi Pendidikan Akuntansi Fakultas Ekonomi Universitas Negeri Yogyakarta. 2017.

[8] Trianto. 2011. Model Pembelajaran Terpadu. Penerbit : Bumi Aksara.

[9] Borg, W. R. \& Gall, M. D. 2003. Educational research: an introduction (7th ed.). New York: Longman, Inc.

[10] Putra, Nusa. 2011. Research \& Development Penelitian dan Pengembangan: Suatu Pengantar. Jakarta: Rajawali Pers.

[11] Warsita, Bambang, 2008. Teknologi Pembelajaran Landasan dan Aplikasinya. Jakarta: Rineka Cipta. 